This item was submitted to Loughborough's Research Repository by the author.

Items in Figshare are protected by copyright, with all rights reserved, unless otherwise indicated.

\title{
"Nature knows no boundaries": a critical reading of UNDP environmental peacemaking in Cyprus
}

\section{PLEASE CITE THE PUBLISHED VERSION}

http://dx.doi.org/10.1080/00045600903245938

\section{PUBLISHER}

Taylor \& Francis (@ Association of American Geographers)

\section{VERSION}

AM (Accepted Manuscript)

\section{PUBLISHER STATEMENT}

This work is made available according to the conditions of the Creative Commons Attribution-NonCommercialNoDerivatives 4.0 International (CC BY-NC-ND 4.0) licence. Full details of this licence are available at: https://creativecommons.org/licenses/by-nc-nd/4.0/

\section{LICENCE}

CC BY-NC-ND 4.0

\section{REPOSITORY RECORD}

Akcali, Emel, and Marco Antonsich. 2019. "'nature Knows No Boundaries": A Critical Reading of UNDP Environmental Peacemaking in Cyprus". figshare. https://hdl.handle.net/2134/16122. 


\title{
"Nature knows no boundaries": a critical reading of UNDP environmental peacemaking in Cyprus
}

\begin{abstract}
:
In 2005, the UNDP set up in Cyprus a peace building project called Action for Cooperation and Trust (ACT). This project has aimed to create opportunities for bicommunal partnerships on environmental protection as a way to promote intercommunal tolerance. The present article aims to critically discuss the efficacy of this project in order to contribute to the debate on the significance of environmental cooperation in transforming ethno-territorial conflicts. Our empirical basis relies on both survey data and the qualified opinions of Cypriot environmental stakeholders. Our analysis shows that, in the case of Cyprus, successful environmental peacemaking strategies are dependent on widespread environmental awareness, trust in the 'third party' (UNDP), and civil society's empowerment, which, however, should complement and not substitute intervention at a state level. There is also evidence to suggest that the UNDP discourse about 'nature knows no boundaries' is most effective when it succeeds to generate solutions which are perceived to be beneficial to all the parties involved, rather than when it uses the environment to discursively construct a common 'patriotism’ beyond ethnic identities.
\end{abstract}

Key words: Cyprus, environment, conflict resolution, UNDP-ACT 


\section{Introduction}

Competing ethno-nationalisms often generate conflicts over the control of the state and the redefinition of territory (Penrose 2002). In 1963, the ethno-nationalist rivalry between the Greek Cypriot (GC) majority and the Turkish Cypriot (TC) minority, competing national interests between Greece and Turkey and the Cold War context led to inter-communal violence in Cyprus. As a result, the TCs -- the main target of this upheaval -- withdrew from the administration of the Republic of Cyprus (RoC), founded in 1960, and created their politico-territorial enclaves. In 1974, Turkey intervened militarily as a response to a coup d'etat launched against the RoC government by GC ultra-nationalists in conjunction with the Greek military junta in order to annex Cyprus to Greece. This led to the territorial partition of the island, with population displacement among both GCs and TCs. Since then Cyprus is divided into the following territorial entities: an internationally recognized RoC; a de facto Turkish Republic of Northern Cyprus (TRNC), embargoed by the international community; two sovereign British military bases, present on the island since 1960; and a UN controlled buffer zone known as ‘the Green Line’ (see Figure 1).

\section{FIGURE 1 APPROXIMATELY HERE. Caption: The Partition of Cyprus}

While TCs generally welcomed the territorial partition, which they felt could offer them a safe haven, the GCs insisted on both the right of return and the temporary nature of this territorial setting (Akçalı forthcoming). In 1977, both sides agreed on a bi-zonal and bi-communal federal solution as the basis for negotiations. However, 
despite decades of peace talks under the auspices of the UN, disagreements between the two administrations have since continued and the two communities remain still today separated. Assuming that the EU membership could fix the Cyprus problem, the RoC applied and was found eligible to join the EU in the 1990s. The expectation was that the EU negotiations and the UN peace talks would go hand in hand.

Yet, on 24 April 2004, the UN plan for the creation of a United Cyprus Republic with two constituent states was rejected by 76 percent of the GCs, whereas 65 percent of the TCs supported it. This meant that the RoC entered the EU alone in May 2004. In summer 2008, the TC and GC leaderships have opened a new negotiation process for a mutually acceptable solution to the division of Cyprus, which, in any case, will be submitted to referendum on both sides. No concrete agreement, however, has so far been reached also in relation to Cyprus’ environmental problems.

Like other countries in the Eastern Mediterranean, Cyprus suffers from water scarcity, droughts, heat waves, forest fires, biodiversity losses, and soil and ecosystem degradation, which are likely to intensify due to climate change (UNDP-ACT 2008a). Despite the fact that, from an ecological point of view, the island is a series of interconnected ecosystems, environmental issues have been addressed separately by the TC and GC political bodies since 1974. Aware of this problem, in 1998, the United Nations Development Program (UNDP) launched in Cyprus a series of bicommunal environmental activities (reforestation, organic farming, waste management, etc.). Experts on both sides started working in parallel on the same environmental issues, but rarely met. With the opening in 2003 of the crossing points which were closed since 1974, the UNDP launched the second phase of its cooperative projects, whereby GC and TC experts worked independently, but met regularly to coordinate their efforts. In the third and present phase, emphasis is on 
joint-projects on which communities work together to protect and maintain environmental assets. Accordingly, in 2005 the UNDP set up a peace building program, Action for Cooperation and Trust (ACT), to create opportunities for bicommunal partnerships which can help care for the island's common natural heritage, while at the same time promoting inter-communal tolerance.

The present article focuses on this latter program in order to analyze the role of environmental cooperation promoted by a third party in transforming ethno-territorial conflicts. The article is divided into three main sections. First, we introduce the research question, by locating it within the literature of environmental peacemaking, environmental management and ethno-territorial conflict transformation. Then, we present the UNDP-ACT initiatives and its underlying discourse. Finally, we critically discuss the UNDP-ACT environmental peacemaking efforts by relying on both survey data and opinions of environmental NGO representatives based in Cyprus.

\section{The role of the environment in conflict transformation}

In their seminal work, Conca and Dabelko (2002) suggest that environmental cooperation between conflict-ridden nations may help overcome political tensions and that civil society plays a crucial role in this process. The underlying logic of this argument is that environmental issues do not recognize any state, ethnic or religious boundary, and have the potential to affect all dimensions of human life. Emphasis on its preservation or dealing with its problems collectively may thus lead the conflicting parties to construct a common identity, which can then transform the conflict communication and the interests of the parties involved (Clayton and Opotow 2003). This logic stems from new understandings of borders as social and dynamic constructions which are open to new and multiple meanings and identities through 
societal changes (Pace and Stetter 2003), and new studies on the transformation of ethno-territorial conflicts which have shifted from state-centered solutions to a wider 'human-needs/world-society framework’ (Richmond 2001). Increasingly important is also the intervention of a 'third party' which has a genuine interest in the successful resolution of the conflict (Miall, Ramsbotham, and Woodhouse 2005, 168).

Despite having some evidence of success and being promising in theory, however, environmental peacemaking as a novel strategy of conflict transformation has been unable to fully convert environmental cooperation into broader forms of political cooperation (Carius 2007, 66). Empirical studies in environmental peacemaking, environmental management and conflict transformation suggest five important points to deal with such a shortcoming.

First, as emerged in peace park studies (Saleem 2007), in order to cooperate, neighboring countries do not have to share common interests, but a common aversion to environmental harms. This implicitly suggests that a widespread environmental awareness is a key factor. Second, environmental peacemaking should be accompanied by cultural, economic, and social development policies, giving way to a so-called 'integrated approach’ to peace-building (Ricigliano 2003). Third, studies on river basin management show that civil society actively participates in environmental programs when they perceive, early in the process, clear evidence of change, win-win solutions, and an equal, transparent, and respectful setting, supported by financial and technical inputs (Tippett et al. 2005). Fourth, besides a civil-society-to-civil-society dialogue, pathways to peace are also created by state-to-state interactions and, most importantly, the interplay between the state and civil society (Conca, Carius, and Dabelko 2005). Finally, external actors need to take into account the importance of 
the symbolic function of borders, for both the state and its people, when designing conflict transformation policies (Wilson and Donnan 1998).

By keeping these points in mind, in the remaining of this article we will critically discuss the role of the UNDP as a 'third party' and its environmental program in Cyprus, as a way to contribute to the debate about environmental peacemaking.

\section{The UNDP and environmental peacemaking in Cyprus}

The first phase of environmental peacemaking efforts of the UN started in 1998, with the Bi-communal Development Program (BDP), aimed at funding peacebuilding and cooperation initiatives benefiting both GCs and TCs. In 2005, the BDP has been replaced by a similar program, called Action for Cooperation and Trust (ACT). Environment is one of the four main sectors of intervention, along with civil society, cultural heritage, and education \& youth. Over the four years of duration (2005-2008), twenty-five environmental projects have been funded, for a total of 3.5 million USD (13 percent of the ACT budget). Although in absolute terms this figure is lower than the one spent during the BDP program (4.3 million USD -- 8 percent of the BDP budget), if one considers the percentage value and the shorter time period of the ACT program (four years against the seven of the BDP), it seems legitimate to affirm that the UNDP in Cyprus has given the environment an increasing role in fostering reconciliation and trust.

The ACT program states that any project which seeks UNDP financial support should be designed and implemented by Cypriots and should enhance cooperation and trust between the two main communities. The program covers various sector of environmental intervention, from sustainable agricultural practices (e.g., organic farming through the use of mycorrhizae) to measures of nature conservation (e.g., the 
rich biodiversity of the Buffer Zone), restoration (e.g., abandoned quarries), and management (e.g., ecology of artificial wetlands). Moreover, in January 2007, thanks to the ACT financial support, the Cyprus Environmental Stakeholder Forum was launched. The Forum, constituted around the Cyprus Technical Chamber (ETEK) and the Union of Chambers of Turkish Cypriot Engineers and Architects (KTMMOB), represents up today the most ambitious project to link together organizations and people from both communities to work on a list of common environmental priorities.

The ACT has also supported the creation of an online environmental directory, which offers detailed information and contact references about all Cypriot environmental NGOs. ${ }^{1}$ By doing so, the ACT hopes to offer both GCs and TCs a tool to identify common interests and generate networking opportunities for environmental stakeholders across the island.

Simply put, the 'philosophy' behind the ACT is that "nature knows no boundaries". "For those who care about the environment in Cyprus, the Buffer Zone, otherwise known as the 'Green Line', does not exist. Air pollution does not stop at, before continuing on its way across, nor are airborne viruses hampered by barbed wire [...]” (UNDP-ACT 2008b). This discursive rendition of the environment aims not only to construct Cyprus 'as one', but also to contribute to the emergence of a common 'civic' identity beyond ethnic differences (UNDP-ACT 2008a, 46), which can help de-securitize the Cyprus question. The belief is that shared environmental awareness and commitment might indeed generate inter-communal solidarity and trust, which, in turn, might lead to wider cooperation on political issues.

As a way to critically engage both this discourse and the actual ACT environmental program, we will discuss survey data regarding the views of both ordinary Cypriots and Cypriot environmental NGO representatives. 


\section{Cypriots and the environment}

Three recent surveys (Eurobarometer 2008; UNDP-ACT 2008c; UNDP-ACT 2008d) will be used here to present Cypriots’ opinions about three relevant topics: environmental awareness, knowledge of bi-communal initiatives, and inter-communal contacts and trust. ${ }^{2}$

Eurobarometer data show that environmental awareness (as measured in terms of knowledge about climate change) is not particularly high among Cypriots. It tends to score, respectively among GCs and TCs, slightly below (54.3 percent) and well below (39.3 percent) the EU-27 average (54.6 percent) (Eurobarometer 2008, 122-124). Overall, GCs show a higher civic commitment to protect the environment, particularly in relation to young and future generations, whereas TCs are relatively less committed and more concerned about the monetary costs involved (Eurobarometer 2008, 140).

As for knowledge of bi-communal initiatives/programs, in 2008 only 12 percent of TCs and 28 percent of GCs heard about them and only 14 percent of TCs and 12 percent of GCs participated in bi-communal events (UNDP-ACT 2008c). These data clearly point to a problem in reaching out the whole population, despite the efforts of the UNDP-ACT in publicizing their initiatives in local mass-media. It is significant that, during the same year, the UNDP-ACT was known only by 12 percent of TCs and 8 percent of GCs (UNDP-ACT 2008c) and civil society organizations were known only to 15 percent of GCs and 12 percent of TCs (UNDP-ACT 2008d).

Scarce environmental awareness and poor knowledge of both initiatives and actors involved in the bi-communal process add to a context of rare inter-communal contacts and trust. In 2008, 86 percent of GCs and 80 percent of TCs declared that they did not have daily contacts with a member of the other community (UNDP-ACT 2008c). In 
the same year, daily border crossings amounted, on average, to 5-6,000 (equal to 0.6 percent of Cyprus's total population) -- a figure, though, which also includes tourists (UNIFICYP 2009). Reciprocal mistrust characterizes both TCs (78 percent) and GCs (66 percent), as also shown by the fact that both communities equally refuse (1.6 out of 4 -- where 4 stands for 'totally acceptable') the possibility of inter-marriage for their children (UNDP-ACT 2008c).

Survey data, though, also show a potential for future collaboration. In fact, 66 percent of GCs and 42 percent of TCs affirmed, in 2008, that "there are a lot of common elements between the two communities” (UNDP-ACT 2008c), whereas only 3 percent of GCs and 11 percent of TCs affirmed that "there are no common elements”. Moreover, data show that those who come into contact with members of the 'other' community tend to become more trusting, although, even in this case, TCs (2.8 -- on a four-point scale) remain more skeptical than GCs (3.3). There is therefore some room for joint initiatives and it is significant that respondents mentioned governmental agencies, NGOs, international organizations, ordinary citizens and the media as those which can have the greatest power in tackling environmental issues. This points to a mix of top-down and bottom-up interventions, as also suggested by the literature. Yet, neither TCs nor GCs listed environmental cooperation among the primary bi-communal programs/initiatives able to promote a solution to the Cyprus problem (UNDP-ACT 2008c), which indirectly calls for an 'integrated approach’ in peacemaking.

\section{Cypriot NGOs and the environment}


As a way to investigate further the UNDP-ACT environmental peacemaking program, we have designed a short questionnaire (see Table 1), which, in June 2008, was sent out to all Cypriot NGOs listed under the UNDP-ACT Environmental Directory. ${ }^{3}$ This list includes a total of sixty-nine NGOs: forty GC, nineteen TC (nine of them, though, are no longer active or they are just an emanation of a larger NGO, such as KTMMOB) and one mixed (recently, however, this latter organization has stopped working, due to financial constraints more than bi-communal problems). A few of them feature expatriates (mainly British) among its active members. Their size varies from the very large (twenty or more staff members) to the very small (only one person).

\section{TABLE 1 APPROXIMATELY HERE. Caption: Frequencies for Greek} Cypriots' and Turkish Cypriots’ answers

Respondents were invited not only to answer 'yes'/‘no' to our questions, but to motivate their answers. After the original email, letter or fax, we contacted again the NGOs by phone and sent additional emails/fax to solicit their answers. The response ratio turned out to be 64 percent for the GC NGOs and 68 percent for the TC ones.

Both the cover letter and the questionnaire were written in English. In general, this did not prove to be an obstacle among GCs, but it turned out to be more so among TCs. In few instances, therefore, we sent out again the questionnaire translated into Turkish and allowed the respondents to answer in Turkish -- the native language of one of the authors.

The format of the questionnaire facilitated the coding process. Data were first coded according to the character (positive, negative, positive\&negative) of the 
opinions expressed and additional codes were generated to capture recurring motives behind these opinions. Analysis relied both on frequencies and content analysis. Here below the respondents’ answers are analyzed separately for GC and TC NGOs.

\section{Greek Cypriot NGOs}

The majority of GC respondents thought that UNDP-ACT initiatives have been effective in generating both environmental awareness and inter-communal understanding and tolerance (see Table 1). Yet, an even greater majority believed that the effects of these initiatives have not been felt evenly among the population, privileging in fact those who already had some environmental awareness.

Those who did not see any obstacles in the idea of using the environment to promote inter-communal tolerance/understanding argued, in line with the UNDP discourse, that "environment is an area which has no boundaries" and which touches equally on "our quality of life". From this perspective, environmental awareness is seen to generate a we feeling inclusive of the whole population, beyond ethnic or religious divides, thus confirming the UNDP discursive strategy of using the environment to foster a common identity. Yet, this view should be analyzed in context. In fact, among GCs, the support for the UNDP-ACT discourse might resonate not only with genuine environmental feelings, but also with a political goal, as the majority of GCs cherish the idea of a reunified island under one central state (International Crisis Group 2006, 20). This is also suggested by the overwhelming majority of GCs who in 2004 rejected the referendum on the UN Plan regarding the creation of a bi-zonal and bi-communal federal Cyprus Republic. This ambiguous overlapping of environmental and political motives surfaced also in some comments of the GC respondents, as, for instance, in the following quote: "when there is a major 
fire in the North people in the South get sentimental and upset, but I think mostly within the concept that the areas that used to be ours are now destroyed”.

The majority of respondents who acknowledged the shortcomings of the use of the environment in transforming the conflictual situation on the island pointed to the unsolved 'political problem'. This was articulated in various terms: “the possession and occupation of one-third of Cyprus by the Turkish army"; "the sensitive property issue” (i.e., GCs claiming properties which they left behind in Northern Cyprus); the “deep resentment (so that I will not use a harsher word), suspicion and mistrust” between the two communities; "ethnic difficulties/differences"; and the fact that “people have principles, they don't want to cross on the other side”. All these views can be synthesized in the following terms: "we need to solve the Cyprus problem first, then environmental cooperation can take place; no the other way round”.

In all these cases, the respondents, whatever their degree of environmental awareness, put their ethno-political belonging first. As a consequence, the environment ceases to be articulated as 'one'; our environment, instead, is cast against their environment, thus defusing any environmental peacemaking: "people in Cyprus worry about environmental problems when it comes to their personal and financial interest [...]. Some of them even think that if there is more pollution or destruction over there, perhaps is for the best as that would suggest that fewer tourists will visit the North”. Clearly, our environment and their environment do not matter to the same extent.

A couple of respondents openly rejected the idea that the environment can play any role in this process. For them, environmental issues concern very few people. On the contrary, according to them, more effective results could come from daily 
activities (e.g., shared business, trade exchanges, and tourism), as these involve many more members of the two communities.

Almost all respondents found that things could have been done differently in order to enhance inter-communal cooperation and trust through environmental initiatives. The most frequent comments revolved around two related issues: more efforts to advertise environmental initiatives through mass-media and to attract ordinary people, not just "the professionals of the environment". This point clearly emerged from the comments of some respondents, who indeed called for more environmental initiatives to be held in schools and among young people in general. Yet, some comments also highlighted the difficulty of "passing the information" to certain categories of people: older generations; new immigrants from Eastern Europe ("their only interest is to make a better life for themselves and to help families left behind in their native countries”); the uneducated; and rural people. Quite a few respondents also advocated more opportunities for GC and TC NGOs to meet directly and one respondent observed that the UNDP "should not use the same methods as in Britain or USA to achieve things”, since “civil society in Cyprus is still very weak.”

\section{Turkish Cypriot NGOs}

Also in the case of TC NGOs, the majority of the respondents maintained that the UNDP-ACT projects have been effective in promoting mutual tolerance and understanding (Table 1). However, only a few of them believed that these projects have successfully raised people’s awareness about the existence of one eco-system on the island. The following quote is illustrative: 
“Any effort targeting the preservation of cultural heritage and the environment raises tolerance, respect and love among people. Environmental awareness efforts are thus effective in raising tolerance among Cypriots in the long term. However, a very long period of common life is necessary in order to raise sensibility to the existence of one eco-system on the island. I am not sure if Greek Cypriots know about the environmental problems in TRNC. The Turkish Cypriots do not have knowledge about the environmental problems in the South, for example.”

According to quite a few of the respondents, the UNDP-ACT projects did not have an impact on all people living on the island, since they targeted mainly NGO members rather than ordinary citizens. Like their GC counterparts, TC respondents also argued that the essence of the problem was elsewhere; as the island's environmental problems simply mirror the political ones. Accordingly, almost half of the respondents mentioned that the international non-recognition of the TRNC and the disadvantages of its de-facto situation constitute a main obstacle to establish intercommunal tolerance and understanding: "Any progress on any issue, whether it is the environment or something else always becomes part of this political problem.” And again: "The Cyprus problem is a political problem. Without resolving it, any initiative of this sort will always have shortcomings. Cooperation and trust can only be achieved through the cooperation of the governments of the two parties.” This suggests two points already discussed by the literature: first, a new emphasis on bottom-up approaches should not come at the expense of a politico-institutional cooperation, as also survey data for Cyprus have indicated; second, environmental cooperation alone cannot make a difference, as this should be incorporated into a more integrated approach to peacemaking. Yet, this also suggests that for some TCs, 
as for some GCs, environmental protection matters as a by-product of peace and reconciliation, not as a tool to foster them.

TC respondents also showed some skepticism towards bi-communal initiatives -something which also emerged in the previously discussed surveys. In their comments, this attitude at times combined with a sense of mistrust towards both the GC counterparts and the third party’s involvement:

"There is no common understanding among the NGOs of both sides. The NGOs on the Greek Cypriot side are opportunists. They declare nuclear energy as an alternative energy because it's for the benefit of their state. They are hesitant to do common projects with us. The NGOs in TRNC are more courageous and seem more forceful, but they do not oppose the environmental degradation that the government policies are causing. The EU, UNDP and USAID, on the other hand, run superficial projects with the Greek Cypriot NGOs which do not have any serious effect for environmental protection.”

This quote exposes a contradictory understanding between TC and GC civil societies about environmental issues. Furthermore, it demonstrates some doubts about the genuine engagement of the third party (the UNDP) with environmental protection and confirms what we have already seen above: any attempt to make peace through cooperation on environmental issues cannot escape the political realm or the 'national interests’ logic.

Finally, all TC respondents agreed that things could have been done differently. In particular, they commented on the inefficacy of some initiatives and suggested to spread environmental awareness to people as a whole, especially to young people, 
through educational projects. They also pointed out to the fact that NGOs are financially underfunded, which explain why they are unable to implement cooperative projects like, for instance, bi-communal youth camps.

\section{Conclusions}

This short article has essayed to critically discuss the UNDP-ACT environmental peacemaking in Cyprus as a way to join the debate on the role of environmental cooperation in transforming conflictual situations. As revealed by both the UNDP surveys and the comments of the respondents to our questionnaire, there is a high level of ethno-territorial identification, mistrust against the other community, and loyalty to the state among both the public and, to a less extent, the environmental stakeholders in Cyprus. Often the environment is divided along ethno-territorial lines, so that our environment matters more than their environment. Alternatively, the environment tends to be perceived as an isolated matter, rather than a tool in fostering discourses of peace and reconciliation. In this case, environmental cooperation becomes a by-product of the transformation of the conflict, rather than a factor in this transformation. This suggests that the conflict communication in Cyprus has not remained contained within the ethno-territorial conflict proper, but has become an omnipresent reference in societal communication. ${ }^{4}$ This situation obviously complicates the bottom-up efforts of environmental peacemaking in Cyprus and calls for continuing politico-institutional cooperation which can complement these efforts.

This complicated scenario is, however, compensated by a sense of shared commonality and support for bi-communal activities, which, according to the UNDP surveys, exist among TCs and, even more so, among GCs. Although not alone, but as part of an integrated approach to peacemaking (Ricigliano 2003), environmental 
cooperation has, therefore, the potential to help generating pathways to peace in Cyprus. Yet, this potential is somewhat conditioned by four factors: the degree of environmental awareness among the population involved; the level of trust of the civil society towards the third party; the degree of civil-society-to-civil-society dialogue; and the degree of effective interaction between civil society and state institutions.

Survey data suggest that much more needs to be done to spread environmental awareness among Cypriots and, in particular, among TCs. Similarly, the respondents to our questionnaire pointed to the fact that the UNDP-ACT initiatives have too often impacted on those already environmentally aware, rather than on the population as a whole. Being the commissioner of two of the surveys discussed in this article, the UNDP is well aware of this problem and in the future is planning to target more directly young generations and to strengthen the Cypriot civil society through a new 2008-2011 bi-communal financial scheme. ${ }^{5}$ This will hopefully tackle also some of the concerns expressed by a few TCs about the credibility of the UNDP as a 'third party'. The new financial scheme is expected to endow both TC and GC civil societies with new financial and technical means which can ease the dialogue between them. Our argument, however, is that this dialogue should not remain confined within the civil society alone, as a civil-society-to-civil-society dialogue must complement rather than simply substitute the traditional politico-institutional negotiations and new forms of dialogue between civil society and state institutions should also be supported.

Finally, the UNDP "nature knows no boundaries" discourse should be reconsidered in order to address the TC skepticism. In fact, while this discourse can generally be favored by the GCs, in line with the official territorial integrity discourse of the RoC, the same discourse might encounter the resistance of those TCs who still 
hold bitter memories of the RoC before 1974. Therefore, instead of using this discourse to foster a common 'civic' identity, a better strategy would be to emphasize more the positive and mutual changes emanating from bi-communal environmental cooperation. It is not a coincidence that, among the 25 projects, the protection of the biodiversity in Buffer Zone, for instance, has been one of the most successful initiatives, also in terms of public visibility, as both sides have equally perceived the benefits. Similar projects, which target the small scale and leave out the 'big' politics, also help the empowerment of the civil society and enhance trust and credibility in the ‘third party’ as well.

Tab. 1 Frequencies for Greek Cypriots’ and Turkish Cypriots’ answers

\section{Greek Cypriots}

\begin{tabular}{|c|c|c|c|c|c|c|}
\hline Questions & YES & NO & YES and NO & DK & NA & TOT \\
\hline 1 & 9 & 6 & 7 & 4 & - & 26 \\
\hline 2 & 8 & 6 & 7 & 4 & 1 & 26 \\
\hline 3 & 5 & 15 & 1 & 3 & 2 & 26 \\
\hline 4 & 9 & 10 & 3 & 1 & 3 & 26 \\
\hline 5 & 14 & 2 & - & 1 & 9 & 26 \\
\hline
\end{tabular}

\section{Turkish Cypriots}

\begin{tabular}{|c|c|c|c|c|c|c|}
\hline Questions & YES & NO & YES and NO & DK & NA & TOT \\
\hline 1 & 3 & 6 & 4 & - & - & 13 \\
\hline 2 & 8 & 3 & 2 & - & - & 13 \\
\hline 3 & 1 & 4 & 8 & - & - & 13 \\
\hline 4 & 12 & - & 1 & - & - & 13 \\
\hline 5 & 13 & - & - & - & - & 13 \\
\hline
\end{tabular}

Questions: 1. Do you think the ACT environmental projects have been effective in arising people's awareness about environmental issues in Cyprus and sensibility to the existence of one eco-system on the island? 2. Do you think this emphasis on environmental issues has been effective on promoting intercommunal tolerance and mutual understanding? 3. Do you think these projects have had an impact on all people on the island? 4. What kind of shortcomings or obstacles do you see in the idea of using the environment to promote inter-communal tolerance and mutual understanding? 5. From your experience, is there anything that could have been done differently in order to enhance the goal of promoting cooperation and trust through environmental initiatives?

DK (Don’t Know), NA (Not answered) 


\section{ACKNOWLEDGMENTS}

We are extremely grateful to both the UNDP in Cyprus and the respondents of our questionnaire. Many thanks also to the two anonymous reviewers and the editor.

\section{References}

Akçalı, E. (forthcoming), La Question Chypriote-Une approache en Nouvelle Géopolitique. Paris: L’Harmattan.

Carius, A. 2007. Environmental Peacebuilding. ECSP Report 12, Woodrow Wilson International Center for Scholars http://www.wilsoncenter.org/topics/pubs/CariusEP12.pdf (last accessed 14/02/2009).

Clayton, S., and S. Opotow eds. 2003. Identity and the natural environment. Cambridge, MA: MIT Press.

Conca, K., and G. Dabelko eds. 2002. Environmental Peacemaking. Washington D.C.: Woodrow Wilson Center.

Conca, K., A. Carius, and G. Dabelko. 2005. Building peace through environmental cooperation. In State of the World 2005, ed. Worldwatch Institute, 144-155. New York: Norton.

Eurobarometer. 2008. Europeans' attitudes towards climate change. http://ec.europa.eu/public_opinion/archives/ebs/ebs_300_full_en.pdf (last accessed 20/01/2009). 
International Crisis Group. 2006. The Cyprus stalemate.

http://www.crisisgroup.org/home/index.cfm?id=4003\&l=1 (last accessed 16/02/2009)

Miall, H., O. Ramsbotham, and T. Woodhouse. 2005. Contemporary Conflict Resolution. Oxford: Polity.

Pace, M., and S. Stetter. 2003. A literature review on the study of border conflict and their transformation in the social sciences, EUBorderConf project, http://www.euborderconf.bham.ac.uk/publications/files/stateoftheartreport.pdf (last accessed 14/02/2009).

Penrose, J. 2002. Nations, states and homelands. Nations and Nationalism 8:277-297.

Richmond, O. P. 2001. A Genealogy of Peacemaking. Alternatives 26:317-348.

Ricigliano, R. 2003. Networks of effective action: Implementing an integrated approach to peacebuilding. Security Dialogue 34:445-462.

Saleem, H. A. ed. 2007. Peace Parks. Cambridge, Mass.: MIT Press.

Stetter, S. 2003. Methodological Annex to 'The EU and the Transformation of Border Conflicts: Theorising the Impact of Integration and Association', EUBorderConf project, http://www.euborderconf.bham.ac.uk/publications/files/methodology1.pdf (last accessed 14/02/2009)

Tippett, J., B. Searle, C. Pahl-Wostl, and T. Rees 2005. Social learning in public participation in river basin management. Environmental Science and Policy 8:287-299. 
UNDP-ACT 2008a. Corporate environmental responsibility in Cyprus.

http://www.undp-act.org/main/data/articles/cer_en.pdf (last accessed 16/02/2009).

---. 2008b. Environment. http://www.undp-act.org/main/default.aspx?tabid=63 (last accessed 11/02/2009).

---. 2008c. Level of trust between the two communities in Cyprus. Nicosia: RAI Consultants Ltd.

---. 2008d. Perceptions on sustainable development and climate change in Cyprus. Nicosia: RAI Consultants Ltd.

UNIFICYP. 2009. Crossing details. http://www.unficyp.org/nqcontent.cfm?a_name=crossing_details_1 (last accessed 20/01/2009).

Wilson, T. M., and H. Donnan eds. 1998. Border Identities. Cambridge: Cambridge University Press.

Correspondence: POLSIS, University of Birmingham, Edgbaston, Birmingham, B15 2TT, United Kingdom, e-mail: e.akcali@bham.ac.uk, emelakcali@gmail.com (Akçalı); GEES, University of Birmingham, Edgbaston, Birmingham, B15 2TT, United Kingdom, e-mail: m.antonsich@bham.ac.uk (Antonsich)

\footnotetext{
${ }^{1}$ The directory is available at http://mirror.undp.org/cyprus/endir/search.asp.

${ }^{2}$ The Eurobarometer survey (Eb 69.2) was administered during April 2008, on a sample of 504 GCs and 500 TCs. RAI Consultants carried out both UNDP-ACT surveys, the first, in September 2008, on a sample of 1,153 GCs and 1,011 TCs (UNDP-ACT 2008c), and the second, in December 2008, on a sample of 412 GCs and 248 TCs (UNDP-ACT 2008d). These surveys are available upon request from the UNDP-ACT.
} 
${ }^{3}$ http://mirror.undp.org/cyprus/endir/EnvDir_En_2005.pdf

${ }^{4}$ This argument has been adapted from Stetter (2003).

${ }^{5}$ Anonymous interview with a UNDP-ACT senior representative (29 August 2008, 12 January 2009). 